OECDpublishing

\title{
GROWTH
}

POLICIES AND

MACROECONOMIC STABILITY

OECD ECONOMIC POLICY PAPER

February 2014 No. 8 



\section{Growth Policies and Macroeconomic Stability}

This paper has been prepared by:

Douglas Sutherland

Peter Hoeller 
The OECD Economic Policy Paper Series is published on the responsibility of the Secretary-General of the OECD. The opinions expressed and arguments employed herein do not necessarily reflect the official views of the Organisation or of the governments of its member countries.

An earlier version of this paper was discussed at the Working Party No. 1 of the OECD Economic Policy Committee. The authors would like to thank the participants.

Series: OECD Economic Policy Papers

ISSN 2226583X

This document and any map included herein are without prejudice to the status of or sovereignty over any territory, to the delimitation of international frontiers and boundaries and to the name of any territory, city or area.

The statistical data for Israel are supplied by and under the responsibility of the relevant Israeli authorities. The use of such data by the OECD is without prejudice to the status of the Golan Heights, East Jerusalem and Israeli settlements in the West Bank under the terms of international law.

(c) OECD 2014

You can copy, download or print OECD content for your own use, and you can include excerpts from OECD publications, databases and multimedia products in your own documents, presentations, blogs, websites and teaching materials, provided that suitable acknowledgment of OECD as source and copyright owner is given. All requests for public or commercial use and translation rights should be submitted to rights@oecd.org. Requests for permission to photocopy portions of this material for public or commercial use shall be addressed directly to the Copyright Clearance Center (CCC) at info@copyright.com or the Centre français d'exploitation du droit de copie (CFC) at contact@cfcopies.com. 


\section{Table of contents}

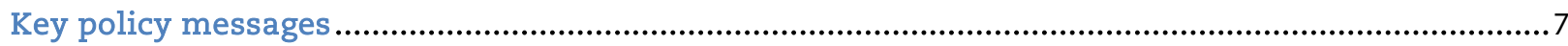

1. Reassessing growth-promoting policies after the crisis .................................................................

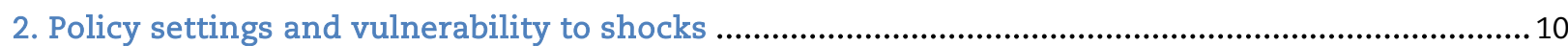

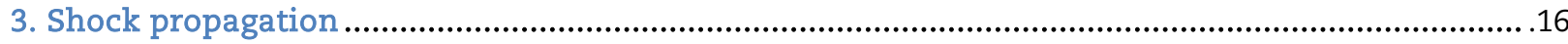

4. Trade-offs and complementarities between growth and stability objectives................................2 24

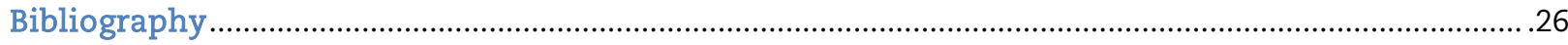

Tables

Table 1. The effects of policies on growth and macroeconomic instability ...................................................9

Table 2. Output gap equations with labour and product market regulation indicators.................................2 21

Table 3. The effects of policies on growth and macroeconomic instability.................................................. 25

Figures

Figure 1. The probability of recession rises when household debt is above trend ...................................... 12

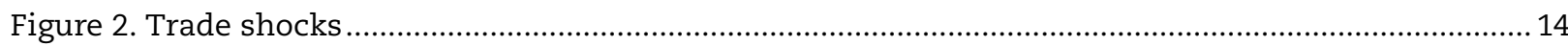

Figure 3. A high debt share and large currency mismatch increase crisis risk ............................................. 15

Figure 4. Country-specific coefficient estimates of shock amplification and persistence..............................22

Boxes

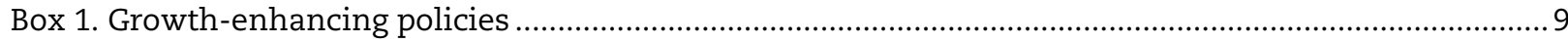

Box 2. The benefits and costs of raising the inflation target................................................................. 17

Box 3. The effects of structural policies on shock persistence and amplification .........................................2 20 


\section{Abstract / Résumé \\ Growth Policies and Macroeconomic Stability}

Policy reforms aimed at boosting long-run growth often have side effects - positive or negative on an economy's vulnerability to shocks and their propagation. Macroeconomic shocks as severe and protracted as those since 2007 warrant a reconsideration of the role growth-promoting policies play in shaping the vulnerability and resilience of an economy to macroeconomic shocks. Against this background, this paper looks at a vast array of policy recommendations by the OECD that promote longterm growth - contained in Going for Growth and the Economic Outlook - and attempts to establish whether they underpin macroeconomic stability or whether there is a trade-off.

JEL classification codes: E32, E52, E62, O40

Keywords: growth, economic policy, business cycles, volatility

\section{$* * * * * * *$ \\ Politiques de croissance et stabilité macroéconomique}

Les réformes visant à stimuler la croissance à long terme ont souvent des effets secondaires - positifs ou négatifs - sur la vulnérabilité d'une économie face à des chocs et à leur propagation. Des chocs macroéconomiques aussi graves et prolongés que ceux observés depuis 2007 justifient un réexamen de la contribution des politiques de promotion de la croissance à la vulnérabilité et à la résilience d'une économie face à de telles perturbations. Dans cette optique, le présent document passe en revue un large éventail de recommandations d'action formulées par l'OCDE pour encourager la croissance à long terme qui figurent dans Objectif croissance et les Perspectives économiques - et cherche à déterminer si les actions recommandées favorisent la stabilité macroéconomique ou si des arbitrages s'imposent.

Classification JEL : E32, E52, E62, O40

Mots clés : croissance, politique économique, cycles d'activité, volatilité 


\section{Growth Policies and Macroeconomic Stability}

\section{Key policy messages}

- OECD policy recommendations aimed at boosting long-run growth often have side effects positive or negative - on an economy's vulnerability to shocks and their propagation. The Great Recession has prompted a review of such recommendations and the extent to which they involve trade-offs between long-run growth and stability and how such trade-offs can be mitigated.

\section{Vulnerability to shocks}

- The OECD Growth Study identified financial market deepening as supporting long-term growth, but the role of the financial sector as a source of instability was not considered. Robust micro and macroprudential regulation needs to be in place to reap the benefits of deep financial markets without increasing economic instability.

- Even with such regulation in place, policy may need to react to emerging threats from the financial sector and asset price bubbles.

- Pursuing price stability over a sufficiently long horizon will allow some leeway for monetary policy to contribute to financial stability. Nonetheless, interest rates are a blunt instrument with the costs felt widely across the economy.

- A regulatory framework that ensures a higher flexibility of housing supply ought in principle to be good for growth and may reduce the risk of house price bubbles, but at the price of greater volatility of building activity, leaving the overall effect on stability unclear.

- Both long-run growth and stability will be served by avoiding debt biases in the tax code particularly for the housing market.

- Trade and financial openness support long-run growth but create vulnerabilities to external shocks. In addressing external imbalances and the risk of sudden stops of capital flows, fiscal policy may sometimes need to be tighter, impediments to direct and equity investment should be removed, and structural and financial policies more generally reformed to remove biases in capital flows contributing to financial account vulnerabilities.

\section{Shock propagation}

- Monetary and budgetary policy settings aimed at low and stable inflation and sound public finances are conducive to long-term growth. Sometimes these policies will also help to contain shocks, but there can be trade-offs.

- Monetary policy that has ensured a firm anchoring of inflation expectations will allow a stronger response to shocks and helps guard against deflationary spirals in the wake of large negative shocks.

- Raising the inflation target could create additional room for monetary policy to react to a severe downturn, but the transition to a new target will involve costs and if the increase in inflation was substantial it would lead to efficiency losses.

- Low government debt levels and sustainable fiscal balances provide fiscal policy room to address large, adverse shocks and absorb liabilities held by other sectors.

- The strength of the automatic fiscal stabilisers depends on the size and progressivity of the tax system and the generosity of the unemployment insurance system. A generous unemployment insurance system and a large and progressive tax system stabilise the economy, but have detrimental growth effects. Making policies state contingent, for instance, 
by prolonging unemployment benefit payments temporarily during a downswing might ease the trade-off.

- Labour and product market policies can affect the size and persistence of a shock.

- Overly tight labour and product market regulations are generally bad for long-term growth. Such policy settings may damp the initial impact of a shock, but could raise its persistence. New findings concerning the recent crisis found no damping effects from such settings, but they still led to greater persistence.

- A number of labour market policies may harm long-term growth and prolong the duration of a shock. They include restrictive employment protection for regular workers, wider coverage of collective agreements and high replacement rates for unemployment benefits.

- Labour market policies that promote employment and growth, such as active labour market policies, are conducive to growth because they help contain the threat of hysteresis during a crisis and also lower shock persistence.

- Short-time working schemes helped cushion the impact of the recent crisis. However, if not well-designed, they may prevent or retard structural adjustment or augment wage pressures, implying a trade-off with long-term performance.

- Tight product market regulation undermines the capacity of an economy to reallocate resources in the face of a major supply-side shock. Light regulation promotes growth and reduces shock persistence.

- $\quad$ Financial sector policies can also influence how shocks are propagated.

- Regulation and supervision to ensure that banks are well capitalised and make sufficient provisions increases the robustness of the banking sector in the face of shocks.

- In the past, policy advice has not examined ways to deal with debt overhangs. Bankruptcy provisions and other institutions that facilitate debt restructuring may help limit the negative drag of deleveraging on consumption and investment. However, this could lead to lenders demanding higher risk premia with potential adverse consequences for growth. 


\section{Reassessing growth-promoting policies after the crisis}

1. The policy recommendations of the OECD - such as those contained in Going for Growth and the Economic Outlook - draw on a large body of empirical work that has identified policy settings which are conducive to long-term growth (Box 1). The underlying analysis has typically paid less attention to their consequences for macroeconomic stability. Such neglect has been supported by the classical finding in the empirical growth literature that average growth and volatility within a country are negatively correlated (Ramey and Ramey, 1995). However, macroeconomic shocks as severe and protracted as those since 2007 warrant a reconsideration of the role growth-promoting policies play in shaping the vulnerability and resilience to macroeconomic shocks.

\section{Box 1. Growth-enhancing policies}

Going for Growth includes structural policy recommendations that enhance living standards through higher productivity and labour utilisation. They broadly cover the areas of product and labour market regulations, human capital and tax and benefit systems. The likely effects of generic policy changes on GDP per capita are shown in Table 1. ${ }^{1}$ Also macroeconomic policy can underpin long-term growth. The OECD Growth Study and OECD work on taxation and growth (Johansson et al., 2008) underlined the benefits of low and stable inflation, small government deficits, low levels of government debt (Sutherland et al., 2010), a small size of government (with the composition of revenue and spending playing a role), openness to trade and deep financial markets in driving longterm growth.

Table 1. The effects of policies on growth

\begin{tabular}{l|c}
\hline A rise in: & $\begin{array}{c}\text { Affects GDP } \\
\text { per capita } \\
\text { with this sign }\end{array}$ \\
\hline Labour taxation and the tax wedge & - \\
\hline Employment protection & - \\
\hline Intermediate collective bargaining & - \\
\hline Collective bargaining coverage ${ }^{2}$ & - \\
\hline Unemployment benefits and their duration & - \\
\hline Spending on active labour market policies & + \\
\hline Early retirement and easy access to disability schemes & - \\
\hline The share of indirect/property taxes in government revenue & + \\
\hline Product market regulation & - \\
\hline FDI restrictions & - \\
\hline Trade policies boosting openness & + \\
\hline Financial market depth & + \\
\hline Prudential regulation & $-/+$ \\
\hline Public debt & - \\
\hline Public deficit & - \\
\hline Target inflation rate (above low levels) & - \\
\hline Target inflation horizon & + \\
\hline
\end{tabular}

Note: The GDP per capita effects are based on the findings of previous OECD and other studies (reported e.g. in Barnes et al., 2011 and Bouis and Duval, 2011).

1. The Going for Growth indicator database is much wider than the policy areas shown in this table, including 34 indicators. Moreover, policy areas with little link to macroeconomic stability, such as agriculture and energy subsidies are not included.

2. The link to growth may be u-shaped with an intermediate extent of coverage detrimental to growth, but high levels better able to internalise the impact of agreements on aggregate outcomes. 
2. Against this background, the link between long-run growth-promoting policies and macroeconomic stability will be reconsidered. Growth-promoting policies can influence macroeconomic stability through a number of different channels. This paper draws on previous work, which examined the implications of structural and macroeconomic policies for economic resilience, counter-cyclical economic policy, macroeconomic risk sharing and external financing and sustainability (Duval et al., 2007; Sutherland et al., 2010; Ahrend et al., 2011; OECD, 2012a, respectively) and presents new empirical evidence based on more recent developments.

3. The remainder of this paper has the following structure. Section 2 discusses pro-growth policies that potentially increase the vulnerability to macroeconomic shocks or contribute to generating unsustainable imbalances, which eventually lead to a sharp correction. The subsequent section considers how policies affect the propagation and persistence of shocks, considering whether policies influence the size and prolong the duration of different types of shocks. The final section provides a synopsis on the effects of growth-promoting policy on the various dimensions of instability.

\section{Policy settings and vulnerability to shocks}

4. This section focuses first on the role of financial markets and then of asset prices on stability before turning to policy settings that expose economies to external trade and financial account shocks.

\section{Well-developed financial markets are beneficial for long-term growth...}

5. The OECD Growth Study (OECD, 2003) highlighted that well-developed financial systems are an important aspect of a growth-friendly environment. A well-developed financial system facilitates the financing of long-term investment and better risk sharing can support investment in higher return projects. When this leads to greater economic efficiency and a better allocation of capital, it is conducive to higher output and perhaps growth (Levine, 2005). While in earlier OECD advice the advantages of welldeveloped financial systems were appreciated, the necessary preconditions to ensure that the financial markets are not a source of instability were largely unaddressed. That said, the Growth Study cautioned that empirical support for the beneficial growth effects of financial market liberalisation relied solely on available quantitative indicators (such as private credit or stock market capitalisation as a per cent of GDP). It also acknowledged the importance of regulatory and supervisory issues, but did not take them into account because of a lack of quantitative and qualitative indicators. ${ }^{1}$

\section{... but can become the epicentre of crises...}

6. The empirical evidence suggests that there does not need to be a trade-off between the growthenhancing effects of deeper financial markets and macroeconomic stability. Indeed, financial market deepening and innovation facilitate greater consumption and investment smoothing, by allowing better risk diversification and inter-temporal smoothing (Blanchard and Simon, 2001; Catte et al., 2004). And deeper financial markets are in general associated with lower output volatility in response to exogenous shocks (Cecchetti et al., 2006; Benk et al., 2009; Céspedes and Velasco, 2012).

7. However, as the Great Recession forcefully demonstrated, financial markets can also occupy the epicentre of macroeconomic crises (Reinhart and Rogoff, 2008; Schularik and Taylor, 2012), and increase the amplitude of the business cycle, when a sharp run-up in lending is followed by a subsequent crash. In this context, financial market policy can encounter a trade-off between promoting growth and avoiding macroeconomic instability. Dynamic and integrated financial markets are prone to more frequent shocks, higher risk of a large shock (Kaminsky and Reinhart, 1999; Taylor, 2012) and pronounced macroeconomic volatility (Buch et al., 2005). Reconciling the diverging evidence on how financial market depth relates to growth and instability, Easterly et al. (2001) identified a non-linear relationship between financial system development and macroeconomic volatility suggesting limits in the ability to smooth consumption and output, as risks mount with the size of the financial sector.

1. A set of regulatory indicators has subsequently been considered in the context of Going for Growth, with certain aspects of stability-oriented regulation but not others found to involve trade-offs with competition in financial markets (OECD, 2010). 
8. The costs of shocks originating in or involving the financial sector are frequently large. Not only is the amplitude of the following downturn large, but the persistence of the shocks is generally higher than for other shocks. For example, Haugh et al. (2009) estimated that the output losses during downturns following banking crises are 2-3 times greater than during normal downturns, while Cerra and Saxena (2008) argued that financial crises can undermine growth for protracted periods. Recent OECD estimates suggest that the current crisis is likely to reduce the average area-wide level of potential output by $3 \%$ on average with the cross-country median effect being around twice as large and the effect being substantially larger still in some countries, such as Greece, Iceland and Ireland (OECD, 2013a).

\section{...so that robust financial market regulation is needed}

9. In retrospect, it is clear that a more nuanced approach to financial market liberalisation would have been warranted. The financial market turmoil during the recent crisis exposed the fragility of financial markets and underlined the need for robust financial market regulation and supervision, including addressing gaps in supervisory coverage, to prevent financial market instability. However, the capacity to eliminate shocks and vulnerabilities originating in the financial sector is limited. Three important aspects are worth noting:

- Regulators need to have sufficient expertise to deal with innovations that may in principle contribute to greater economic efficiency but can also raise vulnerabilities. Financial market crises may be particularly difficult to avoid when markets are newly liberalised or particularly innovative, especially when innovations occur outside the coverage of existing regulation. Reinhart and Rogoff (2008) present evidence that financial liberalisation often precedes a banking crisis, while Dell'Ariccia et al. (2012) find that credit booms often follow financial market liberalisation. Goodhart et al. (2004) note that following liberalisation, underdeveloped financial supervision and risk management skills often lead to a boom in lending, followed by a banking crisis. Innovation can also create difficulties for the regulator even when it is not purposefully aimed at circumventing regulation. For example, the rapid development of over the counter (OTC) products can create operational risks in the absence of clearing houses. And when the market is sufficiently large this can create a systemic risk. The recent crisis exposed unexpected weaknesses in new structured products, in relatively new markets for credit derivatives and, more generally, in maintaining liquidity in securities markets characterised by a high prevalence of OTC products.

- $\quad$ Regulation needs to counteract the incentives embedded in the operation of financial markets, which can encourage excessive risk taking. Incentive problems in the structure of financial institutions and remuneration systems that lead to excessive risk taking in good times need to be addressed.

- Regulation needs to respond to moral hazard problems for systemically important financial institutions that are deemed too important to fail, which may lead to overly risky behaviour. Addressing this issue will require robust microprudential regulation and setting appropriate international regulatory standards.

\section{Pro-growth structural policies do not always raise financial market vulnerability}

10. Structural policies may affect financial sector vulnerability through several channels. First, barriers to foreign direct investment (FDI) and strict product market regulation increase the likelihood of systemic banking crises by encouraging a higher share of bank debt in external liabilities. Second, more favourable tax treatment of interest payments than dividends or capital gains biases (financial as well as non-financial) corporate financing decisions towards debt rather than equity. Third, favourable tax treatment of home ownership may contribute to the build-up of excessive debt burdens by households, which raises the probability of a recession occurring (Sutherland and Hoeller, 2012). In all these cases, more growth-friendly policies would be consistent with (or at least neutral to) greater macroeconomic stability. In contrast, and albeit more speculatively, moving towards more funded pension schemes may for a period boost saving and hence growth but may also have undermined the deposit base of banks leading to more market funding with associated rollover risk. 


\section{Asset price and credit booms often precipitate busts in housing markets}

11. OECD structural policy recommendations identified the development of housing and mortgage markets as bolstering economic resilience and being conducive to higher output as well as in some cases greater resilience to shocks. For example, a well-functioning mortgage and housing market can facilitate labour mobility by reducing barriers to mobility and thus ensure a better matching between firms and jobseekers and easier reallocation in response to certain shocks. Moreover, a deep mortgage market provides an important channel for the transmission of monetary policy, which, in principle, should augment the capacity of monetary policy to stabilise the economy (see below). However, the development of deeper mortgage markets may also contribute to heightened macroeconomic vulnerability. And when these markets crash, the costs are large (Claessens et al., 2012). The danger of housing prices moving beyond equilibrium was recognised by OECD work before the recent crisis (Catte et al., 2004; Van den Noord, 2006), but the associated warnings did not have much influence on policy.

12. One channel for deep and liberal mortgage markets to increase the risk of harmful macroeconomic shocks is through asset price developments allowing households and firms to take on more debt (for example, facilitating mortgage equity withdrawal). When households and firms take on more debt, the possibility of a large shock occurring increases. Empirical analysis in Sutherland and Hoeller (2012) identified factors that help predict recessions, including high levels of private sector debt relative to trend, particularly of the household and the non-financial sector. While the predicted probability of a recession occurring in the following year is around $10 \%$ when household debt is at trend, it rises to over $40 \%$ once debt rises above trend by $10 \%$ of GDP (Figure 1). While the effect sounds large, such an increase above trend is relatively rare. The empirical evidence also suggests that the effects of debt being above trend for the other sectors and for the total economy are less powerful, though rising non-financial corporate debt has a somewhat stronger effect than either rising total economy debt or financial sector debt.

Figure 1. The probability of a recession rises when household debt is above trend

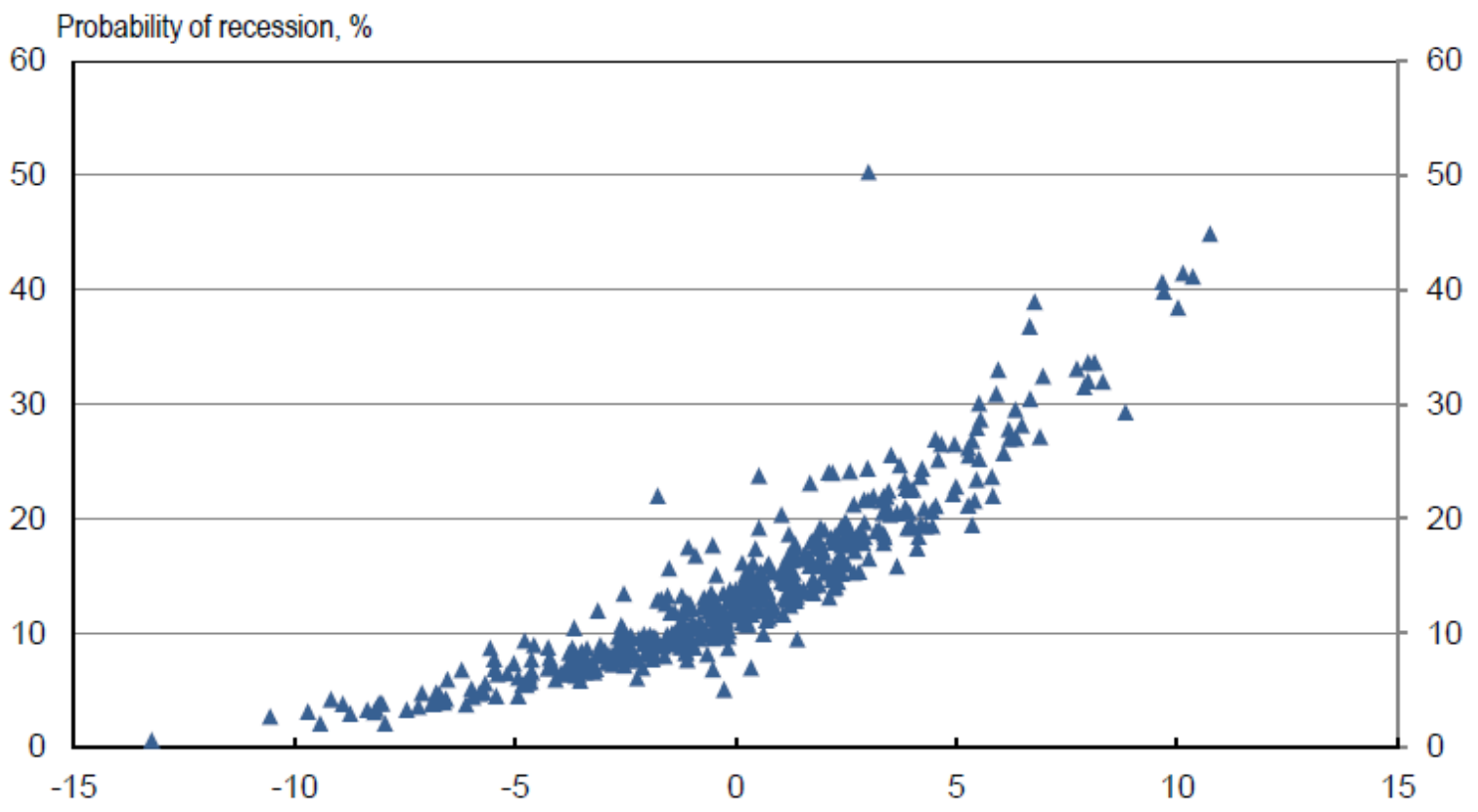

Deviation of household debt from trend, \% of GDP

StatLink त्राजा http://dx.doi.org/10.1787/888932965801

Note: The triangles show for OECD countries the predicted probability of a recession occurring in the following year over the period from 1980 at the earliest to 2010. Household debt is measured as a per cent of potential GDP. When the debt measure is zero, household debt is at the trend value. The probabilities are based on an estimated probit model.

Source: Sutherland, D. and P. Hoeller (2012), "Debt and Macroeconomic Stability: An Overview of the Literature with some Empirics", OECD Economics Department Working Papers, No. 1006, OECD Publishing. 


\section{Several policy options exist to damp the momentum of emerging house price bubbles}

13. Policy options to damp bubbly markets can lead to trade-offs and complementarities with longrun growth. Polices can affect either debt or the run up in asset prices:

- Factors that raise debt-induced vulnerabilities include distortions in the tax code promoting higher debt levels as well as gaps in prudential regulation. Structural policies which encourage borrowing should be reconsidered and reforming them may have a positive effect not only in terms of reducing bubble-like phenomena but also on long-term growth. For example, owneroccupied housing often enjoys special tax treatment such as mortgage-interest relief without taxation of imputed rents. The favourable tax treatment increases household leverage and house price volatility (Andrews et al., 2011). Removing biases in the tax code requires sensitivity in timing to avoid inducing rapid deleveraging, which could depress activity in an already weak economy.

- Prudential regulation can also affect debt levels and hence the risk of instability, though the costs for long-term growth are ambiguous. Prudential regulation may hurt growth by hindering financial intermediation but regulation may also prevent resource misallocation, which should bolster long-run growth. In some countries, strict banking supervision appears to reduce house price volatility (Andrews et al., 2011). Macroprudential policies could play a role in addressing emerging asset price bubbles. For example, either imposing limits on loan-to-value ratios or adjusting them in accordance with housing market developments could provide an important tool in a macroprudential toolkit. Lower loan-to-value ratios are associated with less severe housing downturns (IMF, 2011) and lower incidence of mortgage default (Wong et al., 2011).

\section{Should monetary policy respond to asset price movements?}

14. Monetary policy set too narrowly to maintain low and stable inflation in the near term can be associated with rising vulnerabilities created by an inflating asset (and credit) bubble. This may happen, when inflation expectations are well anchored and growth is inflation free, leading to low interest rates. This may be a risk particularly in the context of a (temporary) favourable supply shock, such as that affecting OECD economies with the greater participation of emerging economies in trade. Monetary policy set to maintain low inflation did not counteract the asset price and credit boom prior to the recent crisis (Ahrend et al., 2008).

15. Whether monetary policy should respond to asset price movements is a long-standing debate. Bernanke and Gertler (2000) make the case that (over) reacting to asset price developments over and above the impact they have on inflation and output is destabilising. On the other hand, Cecchetti et al. (2000) and White (2009) argue that by reacting to asset price misalignments - though not necessarily with the intention of bursting bubbles - inflation targets and low output volatility can be achieved. Robust microprudential regulation and macroprudential policy may in most cases allow monetary policy to concentrate on traditional stabilisation objectives. This would be in line with the Tinbergen Rule that each policy objective is best pursued by the use of separate policy instruments. As business and asset price cycles typically persist for different durations having separate instruments would ensure that the policy instrument is set appropriately for attaining the given target. However, when prudential policies are insufficient, monetary policy may need to take into account financial stability, possibly by having a sufficiently long time horizon for the inflation objective. An operational way to take into account financial stability is to focus on credit growth and asset price developments (Borio, 2012). However, the bluntness of interest rate changes on the economy may make efforts to damp an emerging bubble costly, particularly if part of the asset price developments is driven by changes in fundamentals.

16. In common currency areas, the common monetary policy stance will rarely be appropriate for all members. For example, during the run up to the Great Recession, real interest rates were negative in some euro area countries (Spain, Greece and Ireland). In this context, monetary policy cannot be expected to address unsustainable dynamics in local housing markets, which instead will require effective macroprudential regulation to prevent asset prices getting too far out of line with fundamentals. 


\section{Trade openness tends to boost growth, but exposes countries to external shocks}

17. Trade liberalisation is an important element in OECD policy frameworks. It confers important long-run benefits by promoting economic efficiency and risk sharing, but it can also expose countries to external shocks. There is a considerable body of evidence associating trade openness with long-term growth and OECD structural policy advice has been predicated on this relationship. However, a number of empirical studies find that trade openness is correlated with greater output volatility (Karras and Song, 1996; Easterly, et al., 2001). Trade integration can affect macroeconomic volatility through a number of channels, depending on how it affects trade specialisation. For countries specialised in inter-industry trade, industry-specific shocks can be important in driving business cycles. Countries with greater intraindustry trade specialisation, on the other hand, may enjoy lower output volatility. For OECD countries, the bilateral relationship reveals a strong positive relationship between the volatility of exports and growth volatility (Figure 2). The bilateral relationship for term-of-trade shocks also displays a positive correlation (Figure 2). Terms-of-trade shocks can be large, persistent and account for a sizeable share of macroeconomic volatility in OECD and developing countries, especially for small open economies (Mendoza, 1995; Kose, 2002). Flexible exchange rates help to absorb terms-of-trade shocks (Andrews and Rees, 2009), but other policy options available to insulate the economy from trade and terms-of-trade shocks are very limited. Some countries have established sovereign wealth funds. In other countries, flanking policies which affect the propagation of shocks are likely to be of great importance (see below).

\section{Figure 2. Trade shocks}

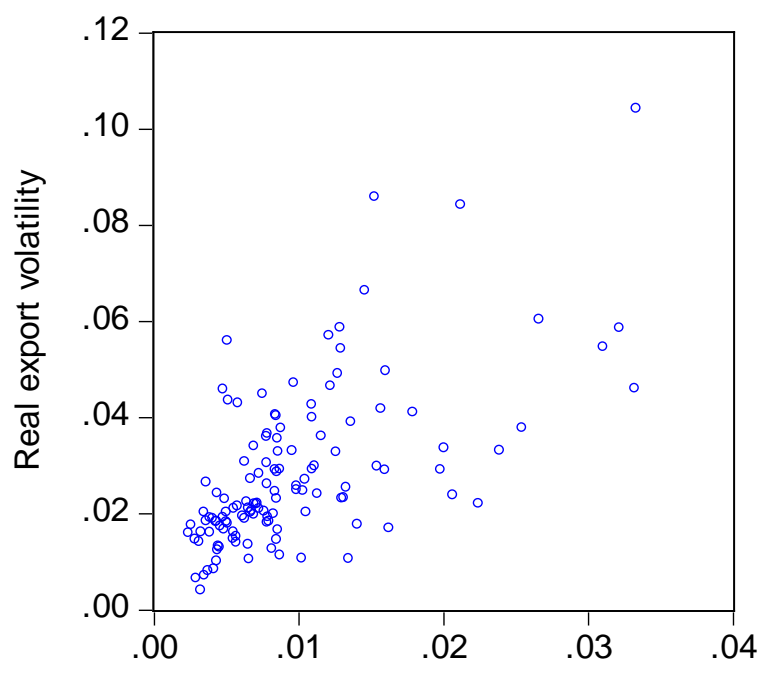

Real output volatility

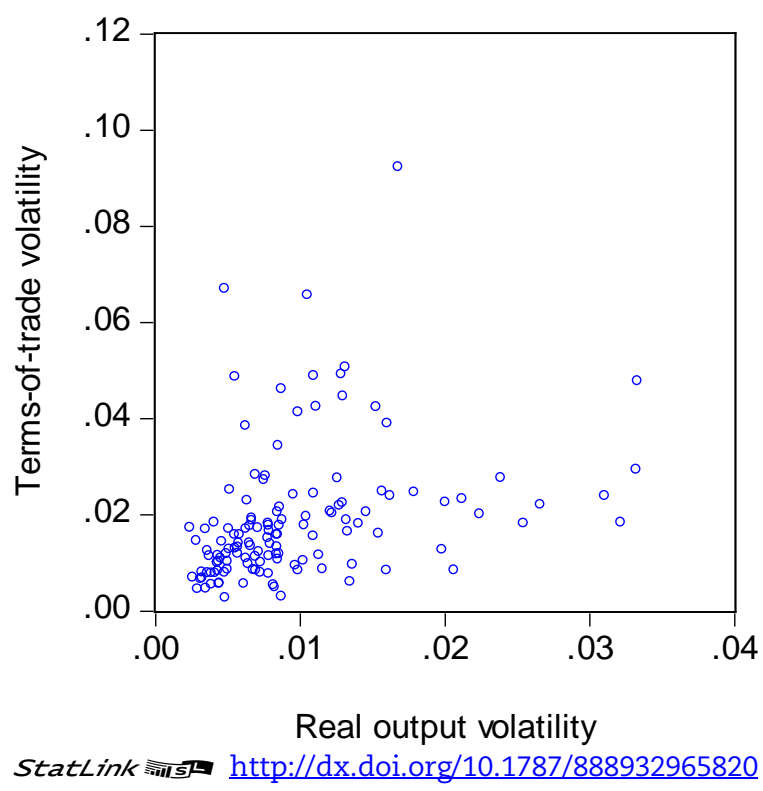

StatLink न्ताlst http://dx.doi.org/10.1787/888932965820

Note: The figure shows non-overlapping volatility for five year periods. Volatility is measured by the standard deviation of quarterly changes over 20 quarters.

Source: OECD (2012), OECD Economic Outlook No. 92, Statistics and Projections (database).

\section{While financial openness confers benefits, foreign financial shocks can be sizeable}

18. Financial openness can in principle offer important advantages in terms of long-term growth and welfare. For example, openness allows greater portfolio diversification and possibly higher rates of return and by facilitating foreign direct investment, openness can spur innovation and productivity growth (Andrews and Criscuolo, 2013). For the recipient country, openness allows greater risk sharing and will help smooth output in the face of idiosyncratic shocks. Pre-crisis empirical work has demonstrated a decline in the "home bias" in OECD countries, suggesting that financial markets offer risk sharing opportunities (Lane and Milesi-Ferreti, 2007).

19. While conferring benefits, financial openness also exposes economies to volatility in financial flows. There is some evidence that financial flows have become more volatile over time and tend to be 
pro-cyclical (Broner et al., 2013). Capital account liberalisation without sufficiently developed financial markets can lead to increased volatility (Dell'Ariccia et al., 2008). Even with well-developed financial markets, vulnerabilities may build in the financial account, heightened, for example, by a large share of debt, especially of (short-term) bank debt in total external liabilities and currency mismatches (Figure 3) (Ahrend and Goujard, 2012; Ahrend and Schwellnus, 2012). Abrupt swings in lending can lead to sudden stops, put pressure on exchange rates and leave domestic financial institutions vulnerable to default risk.

20. As with domestic financial market liberalisation, framework regulations could help minimise the trade-off between policy objectives. The fact that fast rising house prices are associated with a bias towards external debt suggests that macroprudential policies directed towards housing market developments may contribute to reducing this bias (Ahrend and Goujard, 2012). More controversially, and in the absence of other policy responses, targeted capital controls have been found to influence the structure of external liabilities and thus financial stability and could be considered (Ahrend and Goujard, 2012). However, capital controls risk fragmenting international capital markets and could thus be particularly costly. Structural policies can also play a role in reducing the risk of foreign financial shocks. In particular, tax codes that bias debt over equity finance appear to contribute to a higher risk of financial crises because they bias capital inflows towards more volatile debt flows. Tax treaties that encourage foreign direct investment and structural policies that remove barriers to FDI and enhance product market competition appear to reduce the risk of a banking crisis, by removing biases towards relying on debt rather than equity in foreign funding. Recent evidence also suggests that trade openness reduces vulnerabilities to sudden stops in capital flows (Frankel and Cavallo, 2013).

Figure 3. A high debt share and large currency mismatch increase crisis risks

Countries' annual probability of a systemic banking crisis depending on the debt share and currency mismatch Per cent
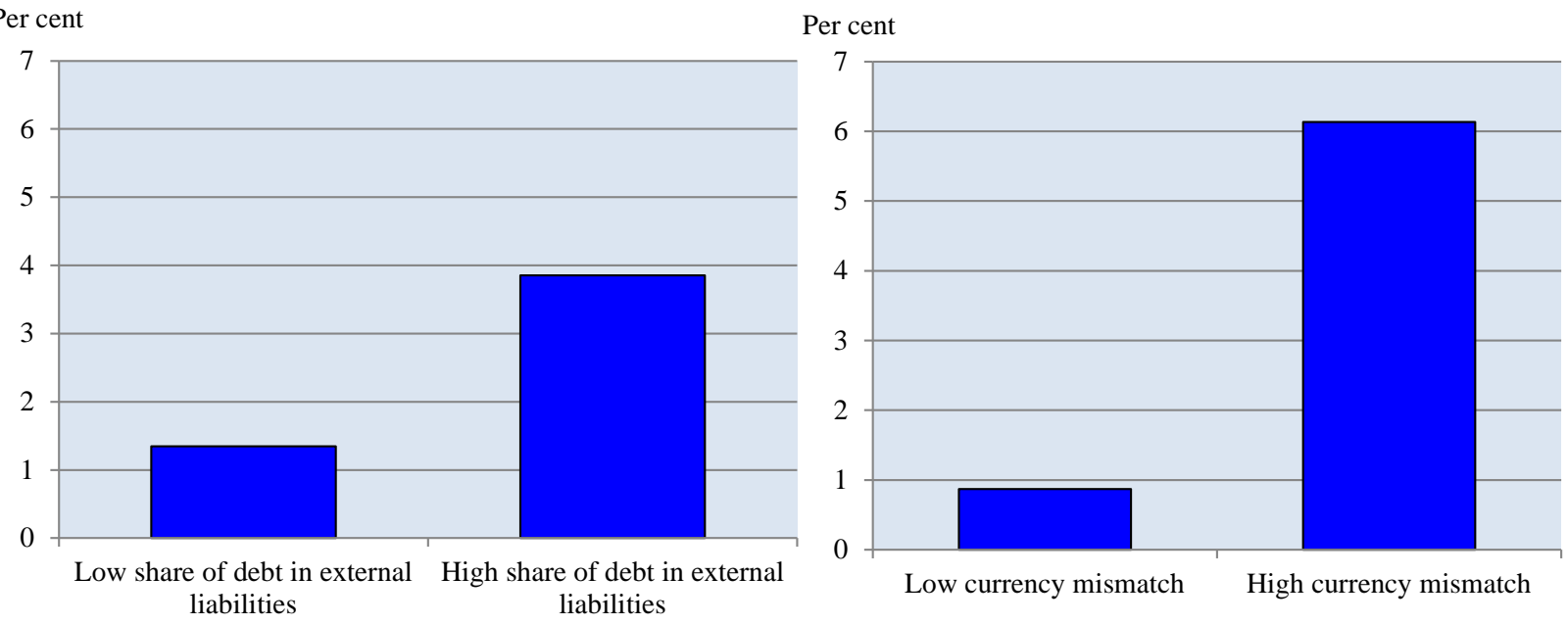

StatLink הilst http://dx.doi.org/10.1787/888932965839

Note: Bars represent, for two possible levels of the share of debt in external liabilities (the currency mismatch), the annual probability of suffering a systemic banking crisis. OECD countries are split into two equally-sized groups based on the size of their share of debt in external liabilities (currency mismatch). The low share of debt in external liabilities (low currency mismatch) is defined as the average across the low debt-share (low currency mismatch) group, with the high share of debt in external liabilities (high currency mismatch) being defined correspondingly.

Source: OECD calculations based on Ahrend and Goujard (2012).

\section{Fiscal and structural policies influence the size of external imbalances}

21. Growth-enhancing policies influence domestic saving and investment and thereby external imbalances. While sometimes consistent with promoting long-term growth and welfare, persistent external imbalances raise the risk of a disorderly adjustment. Given the macroeconomic consequences, the appropriate fiscal policy when current account deficits are large acquires even more importance. Changing fiscal policy in response to external imbalances - which may be largely driven by private sector saving and investment decisions - may be an appropriate response, if it is offsetting distortions in factor markets that are impossible to correct otherwise (Blanchard, 2007). Recent work suggests that a fiscal tightening can reduce external deficits and that the impact may be sizeable, with estimates suggesting 
that a $1 \%$ of GDP tightening of the fiscal balance raises the current account balance by up to around $0.5 \%$ of GDP (Chinn and Ito, 2008; OECD, 2011). As countries with external account deficits are also often countries with large fiscal consolidation needs, Schwellnus (2013) shows that pursuing consolidation combined with structural reforms, particularly in labour markets, could make a contribution to addressing imbalances.

22. In countries running current account surpluses, addressing external imbalances may incur no trade-off with policies promoting long-run growth (OECD, 2011). Of course, surplus countries have less motivation to adjust, but they may still wish to do so if the instability emerging from deficit countries threatens to spill over, such as through heightened credit risk, or if net asset positions are affected by the risk of write-downs. Surplus countries have a variety of policy options to address imbalances. For example, product market deregulation in sheltered sectors may help reduce the imbalances by promoting investment, and pension reforms that increase the length of the working life and raise the retirement age would act to reduce household saving (at least for a while), while also boosting growth.

\section{Shock propagation}

23. Growth-promoting macroeconomic and structural policies not only influence the occurrence of shocks, but also the propagation of those shocks that do occur, determining their size and persistence. The first part of this section considers the role of macroeconomic stabilisation and financial market regulation, mainly through the lens of smoothing shocks. The second part considers growth-promoting structural policies and shock propagation, addressing effects on shock size and persistence.

\section{Growth-promoting macroeconomic policy settings}

24. Three aspects of macroeconomic policy settings received particular attention in the original Growth Study. the benefits of maintaining low and stable inflation; the impact of government deficits on private investment; and, the possibility of negative impacts on growth stemming from a too-large government sector (with the associated heavy tax burden to finance high government expenditure). In the latter case, however, it has been recognised that societal choices may differ and that institutional settings may mitigate the influence of government size on growth and recommendations to countries have been made in this spirit.

\section{What parts of monetary policy need to be reconsidered?}

25. Monetary policy geared towards low and stable rates of inflation underpins long-term economic growth and helps anchor inflation expectations thereby allowing a stronger response to shocks and providing a bulwark against a deflationary spiral in the wake of large shocks. However, low inflation rates may also have negative side-effects for economic stability by limiting room for manoeuvre in the case of a severe adverse shock.

26. At least up until the Great Recession, changes in the conduct of monetary policy were seen as having made inflation stabilisation compatible with output stabilisation. Flexible inflation targeting, including considering longer horizons when setting monetary policy (discussed above), allows monetary policy to be more aggressive in stabilising the real economy as inflation expectations are well anchored. Indeed, in the wake of the crisis inflation expectations have remained well anchored and price stability objectives have largely been met, which allowed a highly accommodative monetary policy to be pursued. However, highly accommodative monetary policy has not delivered a strong recovery in output and employment. In this context, monetary policy has come in for considerable discussion, not only because it did not take into account financial market stability concerns (discussed above), but also due to the difficulty in ensuring a swift recovery from the deep crisis.

27. The difficulties in conducting monetary policy with the usual interest rate instruments during and after the Great Recession provoked a reconsideration of the appropriate inflation target for monetary policy. But the rationale for change comes not only from the implications of large and persistent shocks. An environment of lower and still declining trend growth and hence a low natural interest rate could also imply that monetary policy is set to remain, and perhaps increasingly so, constrained by the zero lower bound. And despite the ability to use unconventional monetary policy instruments, adjusting inflation targets upwards may give monetary policy more scope to react to shocks in the future. That said, adjusting inflation targets involves trading-off some insurance against instability by allowing real interest rates to 
sufficiently undershoot the natural interest rate in bad times against possible efficiency costs associated with higher inflation as well as the transition to such higher inflation (Box 2).

\section{Box 2. The benefits and costs of raising the inflation target}

A somewhat higher inflation target provides central banks more ammunition when facing large adverse shocks and reduces the frequency of hitting the zero nominal bound (Blanchard et al., 2010). A higher inflation rate could be justified if the size of shocks the economy is facing is expected to be higher in the future or if the neutral real interest rate falls (lowering the nominal interest rate that is consistent with a given inflation target). For Japan, where the zero nominal bound has constrained monetary policy for a long period of time, Krugman (1998) and later Leigh (2009) suggested raising the inflation target to around $4 \%$.

In general, the empirical evidence suggests that the costs of inflation may not be significantly different between different low and stable inflation rates (Edey, 1994). Furthermore, Summers (1991) suggested that inflation rates of around $3 \%$ could be justified and may have more credibility as monetary authorities would not wish inflation rates to rise much further.

The arguments against raising the inflation target have relied on theoretical considerations, concerns about a costly transition and fears of loss of control. Thus, higher inflation is argued to induce efficiency losses, such as by distorting relative prices (Goodfriend and King, 1997). Furthermore, while such effects may be small, inflation can interact with and augment pre-existing distortions from the tax code (Feldstein, 1983). For example, tax deductibility of nominal interest payments in the presence of higher expected inflation can strengthen the bias towards debt financing. As concerns the transition, and given that the current inflation targets are well-established and accepted by the public, adopting a new target could introduce considerable uncertainty. Achieving similar credibility for a new and higher target could be difficult and costly, especially at a time of high government debt. This again raises the risk of some loss of control, with higher inflation associated with greater inflation variability, which would affect the anchoring of inflation expectations and growth negatively and may require a stronger monetary policy reaction leading to more output volatility.

Against this background, the choice of an appropriate inflation target needs to balance these concerns: the longterm growth costs of higher and perhaps more volatile inflation against the occasional but important costs of a major crisis where monetary policy becomes less effective; and the transitional costs of moving to a different inflation target.

28. The reassessment of monetary policy has also raised the possibility of more far-reaching changes. For example, the absence of memory in inflation targeting at a moment when inflation has been undershooting and unemployment levels remain high is also being questioned. However, the proposals of price-level targeting and nominal GDP level targeting raise issues of implementation and credibility. At this moment it is not clear that a better alternative is available to flexible inflation targeting with a sufficiently long horizon.

29. Pursuing a highly stimulative monetary policy over a prolonged period may have unintended side effects for financial stability. Such implications should be appropriately internalised by monetary policy and measures to minimise negative risks should be adopted. These could include stricter financial supervision and comprehensive macroprudential frameworks and would necessitate better co-ordination between macroprudential and monetary policy.

\section{What parts of fiscal policy need to be reconsidered?}

30. The OECD's fiscal policy recommendations have typically promoted fiscal sustainability and the better targeting of expenditure towards investment in physical and human capital and the elimination of wasteful spending (such as economically and environmentally-harmful subsidies). Partly in recognition of the potential drag on growth imposed by a large government, recent recommendations have sometimes suggested greater targeting (and means testing) of social benefits, while at the same time undertaking reforms to alleviate negative incentive effects. On the revenue side, a recent study on tax and growth underpins recommendations to move the structure of taxation towards immobile tax bases (such as property) and consumption and away from income taxes (Johansson et al., 2008). These policy choices have effects on the automatic stabilisers and the room to react to large shocks. 


\section{The automatic stabilisers reduce income volatility, but may have adverse incentive effects}

31. Typical OECD recommendations have implications for macroeconomic stabilisation through modifying the size of the automatic stabilisers, generally by weakening them. The advocated shift in the structure of taxation from income taxes to consumption-based taxes would, other things being equal, imply that the automatic stabilisers would become smaller and hence would seem to conflict with the stability objective. On the benefit side, general cuts in the generosity of unemployment benefits have sometimes been advocated on long-run efficiency and employment grounds. Such reforms would likely weaken the automatic stabilisers on the spending side and, hence, may run counter to the stability objective.

32. The desirability of the automatic stabilisers needs to be qualified, however. In general, fiscal policy - whether automatic or discretionary - is better suited to smoothing a demand than a supply-side shock, although both types of shock will often occur simultaneously. Attempts to stabilise a shock which is predominantly on the supply side may prolong the adjustment process and risks putting fiscal policy onto an unsustainable track. Moreover, policy settings on the benefit side that strengthen automatic stabilisers may over time weaken an economy's supply side such as when long-lasting benefits lead to unemployment hysteresis.

33. Bearing in mind this caveat, one way to amplify the effect of fiscal policy in a downturn is to use state-contingent policies. For example, eligibility in Canada and the United States for unemployment benefits is prolonged when the labour market deteriorates. Similar arguments could also be made for support for short-time working. One advantage of making the strength of the automatic stabilisers state contingent - apart from easing the trade-off between long-term growth and short-term stabilisation - is to lend greater credibility to fiscal policy (additional stimulus is temporary), which could amplify the multiplier effect (Corsetti et al., 2010). It also has the potential to make a relatively small government size compatible with stronger automatic stabilisers.

\section{There needs to be more fiscal room to react to a downturn}

34. A severe shock may swamp the ability of the automatic stabilisers and additional statecontingent policies to cope and additional policy stimulus may thus be warranted. The ability to do so will depend on the available room to react and the ability of policy to affect the economy.

35. Low government debt levels and sustainable fiscal balances provide room for fiscal policy to address large, adverse shocks by allowing the automatic stabilisers to operate, pursuing discretionary fiscal policy and absorbing contingent liabilities. Furthermore, private sector saving offsets appear to be higher at high public debt levels, which undermines the ability of fiscal policy to stabilise the economy (Roehn, 2010). At the same time, sound public finances are conducive to long-term growth, for instance, by limiting risk premia in government bond markets (though too small and illiquid government bond markets could also pose problems for the efficiency of financial markets).

36. While the tendency of governments to run deficits and its implications for government debt levels were a concern in the past, the speed at which fiscal space can disappear was underappreciated. Indeed, policy advice before the Great Recession, e.g. contained in the Economic Outlook (OECD, 2007), usually couched policy advice in flow terms of improving structural balances rather than explicitly bringing debt levels down and put insufficient stress on the extent to which financial and housing market developments were flattering underlying budget balances. Recommendations for the reduction of debt levels were often couched in terms of making space for future pension or health spending rather than for allowing the automatic stabilisers to operate unhindered, creating space to engage in discretionary fiscal policy and providing scope for absorbing contingent liabilities. Together these can boost debt to uncomfortable levels quickly. When the crisis struck, fiscal positions were insufficiently robust and debt levels already too high given the scale of the downturn and of the contingent liabilities that governments had to assume during the crisis. This contributed to the perceived need to slash deficits in a weak economic environment.

37. In this respect, past OECD recommendations focused too little on reducing debt levels. Commitment to a prudent debt target would provide an anchor for fiscal policy, countering the upward trend in debt experienced in many OECD countries. To the extent that macroeconomic volatility is likely to 
be higher than during the great moderation period, a low debt level would create more fiscal space to cope with future shocks. Prudent debt targets should consider the necessary room to react, taking into account contingent liabilities - e.g. lower targets when the financial sector is large - and also consider the risks associated with the maturity and denomination of debt and liquidity risks due to foreign holdings of debt. However, given current debt levels across the OECD, bringing them down to prudent levels will require a sustained effort over a considerable time horizon for most countries.

\section{The financial sector propagates shocks}

38. As discussed above, financial sector depth supports long-term growth but can also expose the economy to vulnerabilities. The financial sector can also influence macroeconomic stability by amplifying or damping the propagation of a shock. The financial sector can influence shock propagation in several ways. The most direct is when the financial sector becomes impaired in the wake of a severe shock. A credit crunch can amplify the size of a shock and its persistence. Impairment will also reduce the effectiveness of monetary policy (as discussed above). Trade-offs between short-term stabilisation and long-term growth can emerge with policy settings that reduce the cost of deleveraging and boost the shock absorbing capacity of the financial sector, which have arguably received limited attention in the past.

39. Following a ramp up in asset prices and debt levels, the subsequent decline in wealth during the bust pushes households and firms to deleverage. Differences in the ability to renegotiate or default on loans explain some of the differences across countries in the ability to work off debt overhangs. Debt write-downs can hasten deleveraging in the non-financial sector and spur a more vigorous recovery from a high-debt recession and internalise social costs of disorderly bankruptcy. For example, policies and institutional arrangements that aim to reduce the level of household debt relative to assets and debt service relative to repayment capacity can help reduce the fall in consumption and investment (Sutherland et al., 2012). These policies and institutions may come at a cost, however. Bankruptcy and workout regimes that are more friendly to default or restructuring may run the risk that reduced creditor protection will lead to higher risk premia with potential negative consequences for investment and longterm growth (though monetary policy may offset some of this). On the other hand, reforming policies and institutions to become friendlier to restructuring may modify the incentives to engage in risky lending, which may lower bank funding costs and ultimately lending rates. Furthermore, effective bankruptcy procedures may help accelerate adjustment and thereby lower real economy costs, which may help to bring down risk premia.

40. In addressing the financial sector's interaction with the rest of the economy, prudential tools may be useful in insulating the financial sector from shocks and minimising the risks that the financial sector adversely affects shock propagation. The pro-cyclicality of the financial system should be reduced, which is largely in the domain of microprudential policy. In particular, the shock-absorption capacity needs to be raised, which depends on the size of capital buffers and whether provisioning for bad loans provides sufficient buffers during a downturn. However, increasing capital requirements may have an effect on credit and ultimately output (Angelini et al., 2011). For example, Slovik and Cournede (2011) estimated that a 1 percentage point increase in bank capital ratios would reduce the level of GDP by around one-fifth of a percentage point over five years. These estimated effects are relatively small and do not take into account that more solid capitalisation could reduce bank funding costs. In addition, to the extent higher costs of credit were to affect activity relative to potential, monetary policy may also react and contribute to offsetting the effects.

\section{Labour and product market policies also affect shock propagation}

41. Structural policy settings in labour and product markets are important for long-term growth but may also influence how shocks are propagated, potentially affecting both shock size and persistence. The size of the shock will determine whether persistence is likely to arise. For example, large shocks may swamp the ability of macroeconomic stabilisation to smooth the cycle and thus make the structural policy settings more important. Large or protracted cyclical downturns can affect potential output and long-term growth. There may be self-reinforcing mechanisms at play so that what starts out as a temporary downturn ends up with protracted or permanent effects - what Phelps (1994) called a structural slump. Good structural policy settings can thus play an important role in reducing persistence through hysteresis effects, particularly if the shock is large. 
42. The empirical evidence reveals that tight labour and product market regulation can affect shock propagation, mostly leading to greater persistence. Blanchard and Wolfers (2000) showed that unemployment rates increase faster in tightly regulated labour markets following an adverse shock. Building on this study and examining the links between policies and shocks and using pre-crisis data, Duval et al. (2007) showed empirically that strict labour and product market regulations can damp the initial impact of shocks. Their simulations suggest that for most continental European countries the initial impact of a shock is cushioned but the effect is more persistent, with cumulated output losses tending to exceed the ones in most English-speaking countries and a few mostly small European countries (Denmark, Netherlands and Switzerland). Updates of these estimates, taking into account more recent events, cast doubt on the ability of economies with more regulated product and labour markets to cushion the initial impact of shocks better, but confirm that the costs in terms of greater persistence nonetheless remain (Box 3). On the basis of these estimates, structural policies which are conducive to long-term growth would also appear to minimise shock amplification and persistence.

\section{Box 3. The effects of structural policies on shock persistence and amplification}

Following Duval et al. (2007), the effects of labour and product market regulation on the persistence and amplification of shocks are estimated using a regression that disentangles the effect of a shock on the output gap (amplification) and the speed with which the output gap closes (persistence). The estimation procedure allows an evaluation of the effects of policy and institutional settings on amplification and persistence. ${ }^{1}$

The regression results for different labour and product market indicators are shown in Table 2. The analysis covers 1985 to 2012 for the same countries covered in the Duval et al. (2007) study. For product markets, a measure of the importance of state control in the economy is correlated with greater persistence in output gaps and significant amplification of shocks. Furthermore, a measure of regulation in the network industries, which is available for a longer time span, suggests that persistence and to a lesser extent amplification of shocks is also more pronounced in economies with more highly regulated product markets.

In contrast with the earlier work, tight employment protection legislation for regular workers is no longer found to reduce the amplification of a shock (it now seems to amplify the output gaps) and is still associated with greater persistence. The coverage of collective bargaining agreements appears to have an effect on increasing the persistence of the shock, which is in line with the finding reported in Duval et al. (2007). The previous analysis is extended by examining the impact of trade openness and the deepness of financial markets (as measured by the share of private credit as a percent of GDP). Deeper credit markets appear to insulate economies from shocks, even when the analysis covers the Great Recession.

Another way to examine resilience is to modify the non-linear equation above to capture country-specific, rather than policy-specific amplification of common shocks and the persistence of the output gap. The results are presented in Figure 4 below. In contrast to the earlier findings, which covered the periods 1982 to 1990 and 1993 to 2003 , there appears to be less of a trade-off between amplification and persistence when the equation is estimated for the period 1985 to 2012 (although Greece is somewhat of an exception, showing signs of low amplification but pronounced persistence). English-speaking countries tend to experience less persistence in comparison with continental European economies, while shock amplification is not much different, whereas in the past it was somewhat greater than for the continental European countries.

1. The estimation uses the following non-linear specification:

$$
\operatorname{Gap}_{i t}=\left(\varphi+\varphi^{j}\left(X_{i t}^{j}-\bar{X}^{j}\right)\right)\left(\operatorname{Gap}_{i t-1}-\eta G a p_{i t-2}\right)+\lambda_{t}\left(1+\gamma^{j}\left(X_{i t}^{j}-\bar{X}^{j}\right)\right)+\alpha_{i}+\varepsilon_{i t}
$$

where Gap is the output gap as measured in the Economic Outlook 92; $X$ are indicators of labour and product market regulation; $\lambda_{t}$ are time fixed effects; and $\alpha_{i}$ are country fixed effects. The parameters $\varphi^{j}$ and $\gamma^{j}$ capture policy-specific output gap persistence and amplification to common shocks, respectively. 
Box 3. The effects of structural policies on shock persistence and amplification (cont.)

Table 2. Output gap equations with labour and product market regulation indicators

\begin{tabular}{|c|c|c|c|c|c|}
\hline & State control & $\begin{array}{c}\text { Network } \\
\text { regulation }\end{array}$ & $\begin{array}{l}\text { Employment } \\
\text { protection } \\
\text { (regular } \\
\text { workers) }\end{array}$ & $\begin{array}{l}\text { Collective } \\
\text { agreement } \\
\text { coverage }\end{array}$ & $\begin{array}{l}\text { Private credit } \\
\quad(\% G D P)\end{array}$ \\
\hline \multicolumn{6}{|l|}{ General persistence } \\
\hline$\varphi$ & $1.100^{\star \star \star}$ & $1.245^{\star \star \star}$ & 1.190 *** & $1.227^{\star \star \star}$ & $1.207^{\star \star \star}$ \\
\hline$\eta$ & $0.312^{\star \star \star}$ & $0.417^{\star \star \star}$ & $0.365^{\star \star \star}$ & $0.312^{\star \star \star}$ & $0.407^{* * *}$ \\
\hline \multicolumn{6}{|l|}{ Policy-related persistence } \\
\hline State control & $0.112^{\star \star}$ & & & & \\
\hline Network regulation & & $0.102^{\star \star \star}$ & & & \\
\hline Employment protection & & & $0.052^{*}$ & & \\
\hline Collective coverage & & & & $0.004^{\star \star \star}$ & \\
\hline \multicolumn{6}{|l|}{ Trade openness } \\
\hline Private credit (\%GDP) & & & & & 0.062 \\
\hline $\begin{array}{l}\text { Implied half-life of shock at policy } \\
\text { measure one standard deviation } \\
\text { above the mean (years) }\end{array}$ & 1.7 & 4.0 & 1.9 & 2.9 & 2.2 \\
\hline of which general persistence & 1.3 & 2.1 & 1.7 & 2.0 & 2.0 \\
\hline \multicolumn{6}{|l|}{$\begin{array}{l}\text { Policy-related amplification } \\
\text { (marginal impact at mean } \\
\text { reported in parentheses) }\end{array}$} \\
\hline State Control & $\begin{array}{l}0.002^{\star \star \star} \\
(0.722)\end{array}$ & & & & \\
\hline Network regulation & & $\begin{array}{l}0.129 * * \star \\
(0.031)\end{array}$ & & & \\
\hline Employment protection & & & $\begin{array}{l}0.101^{* * *} \\
(0.291)\end{array}$ & & \\
\hline Collective coverage & & & & $\begin{array}{c}0.003 \\
(-0.000)\end{array}$ & \\
\hline \multicolumn{6}{|l|}{ Trade openness } \\
\hline Private credit (\%GDP) & & & & & $\begin{array}{l}-0.266^{\star \star \star} \\
(-0.172) \\
\end{array}$ \\
\hline Observations & 300 & 502 & 446 & 454 & 490 \\
\hline Adjusted R-squared & 0.86 & 0.87 & 0.86 & 0.87 & 0.86 \\
\hline
\end{tabular}

Note. Estimation by non-linear least squared. * ${ }^{* *}$, $\star \star *$ significant at $10 \%, 5 \%$ and $1 \%$, respectively.

Source: OECD Economic Outlook No. 92, Statistics and Projections (database). 
Box 3. The effects of structural policies on shock persistence and amplification (cont.)

Figure 4. Country-specific coefficient estimates of shock amplification and persistence Panel A. Persistence ( $\mathrm{y})$

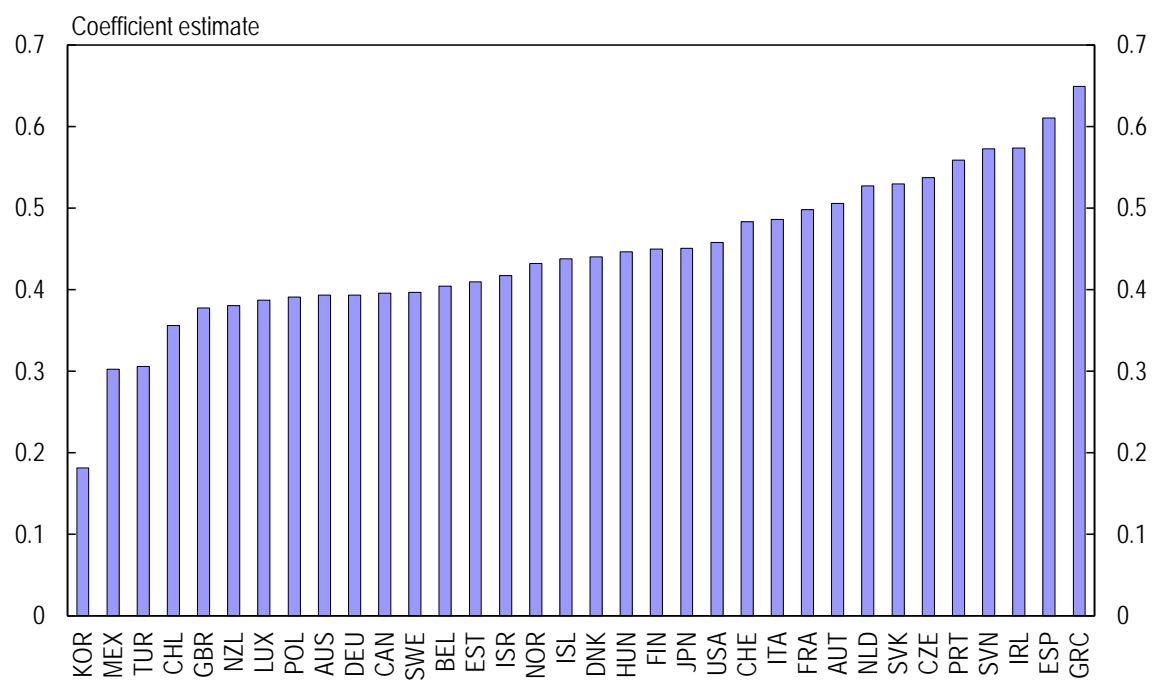

Panel B. Amplification $(\varphi \eta)$

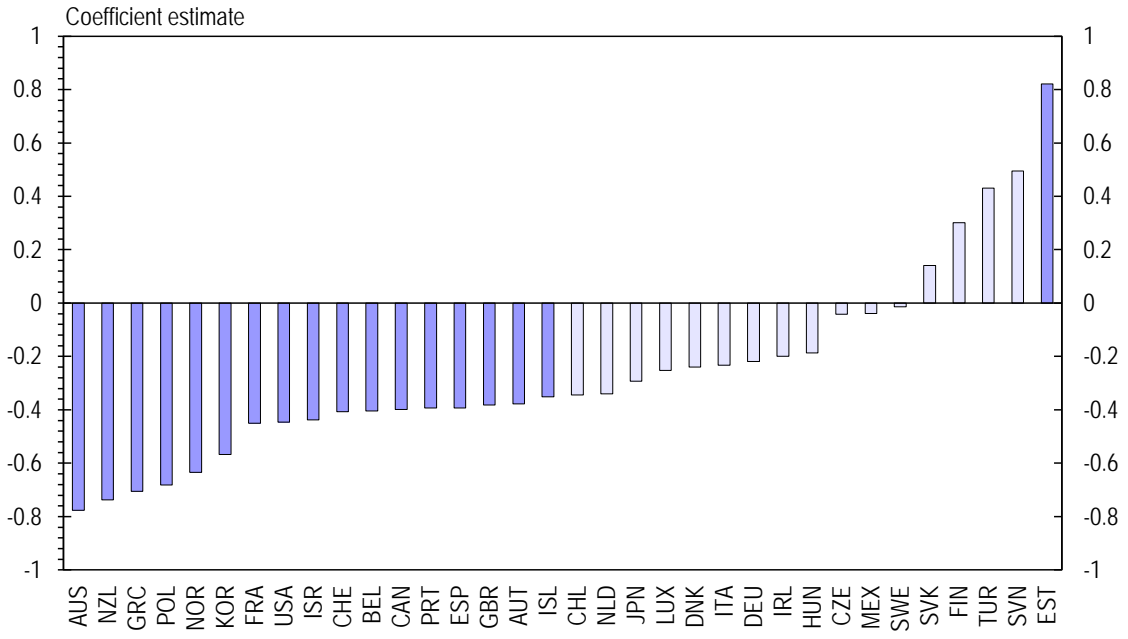

StatLink :insth http://dx.doi.org/10.1787/888932965858

Note: The estimates that are not statistically significant at $10 \%$ are shown as pale bars.

Source: OECD Economic Outlook No. 92, Statistics and Projections (database).

\section{Labour market institutions affect shock amplification and persistence in various ways}

43. The OECD Jobs Strategy and its follow-up in 2006 (OECD, 2006) pointed to the various mechanisms by which labour market policy affects employment and growth. At the same time, however, these policies may also affect the propagation of shocks:

- The tax wedge and labour taxation. Lowering labour taxation supports higher employment. This comes across as a robust general empirical finding in Bassanini and Duval (2006) and Ahrend et al. (2011) found that lower tax wedges can mitigate the deterioration in employment of groups with weak attachment to the labour market. On the other hand, lowering the progressivity of labour taxation and shifting the tax structure away from labour taxation towards bases like 
immovable property reduce the effectiveness of the automatic stabilisers (as noted above), implying a trade-off between growth and stability.

- Active labour market policies. A key plank of employment-boosting labour market policies is activation. Partly as a result of making more use of active labour market policies, OECD countries may have become less vulnerable to labour market hysteresis effects thereby reducing the persistence of shocks to the labour market (Guichard and Rusticelli, 2010). Hence in this policy area there may be synergies between growth and stability.

- Job protection. Earlier work by the OECD (Duval et al., 2007) suggested that tight job protection cushions the impact of a shock, but gives rise to greater persistence of the output gap. Updated evidence reported in Box 3 suggests that the cushioning effect is not present any more, if recent data are included, while the adverse persistence effect is still there. However, the nature of job protection also matters (OECD, 2012c). For instance, stricter protection for workers on permanent contracts favours adjustment in working time and wages rather than through changes in (un)employment, which may help reduce the risk of weakening labour market attachment. But if stringent employment protection for permanent contracts favours the use of temporary contracts, leading to labour market dualism, this can weaken labour market outcomes and increase the persistence of unemployment shocks. Hence the nature of job protection will determine to what extent an easing will bring benefits for both growth and stability or whether there may be trade-offs.

- Wage-setting institutions. Previous analysis has suggested that labour market outcomes are better with both highly centralised and completely decentralised wage-setting institutions, but worse for intermediate institutions. For example, in countries with highly centralised or coordinated wage setting, it is possible to internalise the detrimental employment effects of excessive wage pressures, which may allow the economy to adjust more quickly to shocks (Bassanini and Duval, 2006). However, if shocks are asymmetric across the economy and persistent, adjustment may become more difficult relative to a less co-ordinated system. The estimates reported in Box 3 suggest that wider coverage of collective wage agreements is associated with greater persistence of shocks. Overall, there is evidence to suggest that either highly centralised or highly decentralised bargaining systems are associated with better longterm employment outcomes but the evidence on the effects of the bargaining framework on the stability of output does not lead to any strong general conclusions.

- Unemployment benefits systems. Generous unemployment benefits, and in particular high initial replacement rates and long benefit duration augment the automatic stabilisers and damp the negative impact of shocks, as discussed above. However, these policies also create adverse incentive effects. By reducing the job-search intensity of the unemployed and by lowering the opportunity cost of not working they will raise the persistence of shocks and hysteresis risks Hence policy in this area can face a trade-off between growth and stability.

- $\quad$ Retirement and disability schemes. Retirement (and occasionally in the past disability) schemes with generous provisions tend to reduce employment and growth. However, they can provide a safety valve when an economy experiences a large shock, cushioning the impact on unemployment. However, such policies usually involve irreversible exits from the labour force with durable negative impacts on growth and employment. Hence, any gains in stability will typically be bought at a high price in terms of employment and growth in the long term.

44. Labour market outcomes following the Great Recession suggest somewhat better performance than may have been expected given the size of the shock, with lower productivity being the shock absorber in some countries rather than lower employment. This may tentatively suggest that past labour market reforms, which have aimed principally at improving steady-state employment could have had overall benefits also in terms of employment stability (OECD, 2013b).

45. Finally, the Great Recession induced a number of countries to implement new approaches to minimise the shock to labour markets. For example, short-time working schemes appear to have shielded some labour markets from the full impact of the crisis. As short-time working schemes were viewed as influencing short-run employment dynamics and not long-term growth, they were not considered among the OECD growth and employment-promoting policy recommendations. However, by reducing the inflow into unemployment and reducing the associated risk of hysteresis in the face of a large aggregate demand 
shock, such schemes may bring considerable benefits. On the other hand, in the face of a permanent supply shock that requires a substantial resource reallocation they may involve significant costs by slowing adjustment. Moreover, knowledge that such schemes exist as a shock absorber may also have implications for wage formation, which are not fully known yet. In any case, the design of these schemes is important for realising their potential to enhance stability without incurring costs in the long-term growth and employment dimensions.

\section{Light product market regulation facilitates resource reallocation following an adverse shock}

46. Pro-competitive product market regulations support faster catch-up and stronger growth by reducing monopolistic tendencies and weakening insider-outsider mechanisms while also contributing to a more innovative and dynamic economy (OECD, 2013c). Recommendations to reform product market regulations have been frequent in Going for Growth (OECD, 2012b).

47. Light product market regulation is likely to play an important role in shock propagation by facilitating resource reallocation and thereby reducing the persistence of the shock, especially a supply shock (Box 3). Economies with lower levels of state control in product markets also appear to be better able to withstand large shocks. Product market regulation has little effect on the propagation of demand shocks, but tight regulation has an adverse effect in the case of supply shocks (Sutherland and Hoeller, 2013). On this basis, OECD policy recommendations that have advocated an easing of product market regulations are consistent with lowering the amplification and persistence of macroeconomic shocks and bolstering long-run economic growth.

\section{Deeper credit markets insulate economies from the consequences of common shocks}

48. Housing sector policies have previously been identified as a key factor that could enhance the resilience of an economy to economic shocks (Duval et al., 2007). While housing market and related financial market policies created vulnerabilities to shocks (see above), whether they are detrimental to shock propagation is less clear. Well-developed housing markets can help reduce shock size and persistence by aiding the transmission of monetary policy (Drew et al., 2004; Catte et al., 2004). As a result of a more potent monetary policy, an economy when hit by a negative shock would experience a smaller initial output fall and less persistence. The crisis has cast doubt on the validity of these arguments when financial markets are impaired. However, the regression results reported in Box 3 suggest that deeper credit markets insulate economies from common shocks, even when the analysis covers the Great Recession. Moreover, early evidence following the crisis (Benetrix et al., 2012) supports previous findings, which suggested that housing slumps in countries with well-developed mortgage markets have tended to be shorter.

\section{Trade-offs and complementarities between growth and stability objectives}

49. Summing up, growth-promoting policies along the lines typically promoted by the OECD affect macroeconomic instability in a number of ways. In some cases the policies that underpin long-term growth also support macroeconomic stability in some or all dimensions, while in others there may be a trade-off as they can raise vulnerabilities to shocks as well as amplify shocks and increase their persistence. Table 3 illustrates in a judgemental, simplified and selective manner some of the possible trade-offs and complementarities between growth-enhancing policies and the various stability dimensions that have been discussed above.

- $\quad$ Some growth-promoting policies are likely to enhance macroeconomic stability. For example, bringing public debt levels down is not only good for medium and long-run growth, but can help reduce the different dimensions of macroeconomic instability as it allows the unfettered working of the automatic stabilisers and the use of discretionary policy to cushion a shock. Easing strict product market regulations boosts long-term growth and appears to simultaneously reduce the amplitude of shocks and their persistence, and easier product market regulation also helps ease vulnerability to the extent it favours more stable capital flows. Similarly, easing restrictions on foreign direct investment will support growth and by reducing the bias of capital flows towards debt and the likelihood of external financing shocks, will also buttress macroeconomic stability. 
- For a range of policies, trade-offs exist between long-term growth and some dimensions of instability whereas there may be complementarities with other aspects of stability. For example, financial market liberalisation increases the vulnerability of the economy to shocks. However, deep financial markets can assist monetary policy in damping shock amplification, unless they are impaired, and may limit persistence.

- Finally, a number of growth-enhancing policies, such as those affecting trade and financial openness, may increase the vulnerability of the economy to shocks. In such cases, flanking policies may be needed to insulate the economy better from the adverse consequences of shocks.

Table 3. The effects of policies on growth and macroeconomic instability

\begin{tabular}{|c|c|c|c|c|}
\hline \multirow[t]{2}{*}{ A rise in: } & $\begin{array}{c}\text { Affects } \\
\text { GDP } \\
\text { per capita }\end{array}$ & $\begin{array}{c}\text { Affects } \\
\text { shock } \\
\text { vulnerability }\end{array}$ & $\begin{array}{c}\text { Affects } \\
\text { shock } \\
\text { amplification }\end{array}$ & $\begin{array}{c}\text { Affects } \\
\text { shock } \\
\text { persistence }\end{array}$ \\
\hline & \multicolumn{4}{|c|}{ with this sign } \\
\hline Labour taxation and the tax wedge & - & & $-1+$ & - \\
\hline Employment protection & - & & $(+)$ & + \\
\hline Intermediate collective bargaining & - & & $-1+$ & + \\
\hline Collective bargaining coverage & - & & - & - \\
\hline Unemployment benefits & - & & - & + \\
\hline Spending on active labour market policies & + & & & - \\
\hline Early retirement and easy access to disability schemes & - & & - & + \\
\hline The share of indirect/property taxes in government revenue & + & & + & - \\
\hline Product market regulation & - & + & + & + \\
\hline FDI restrictions & - & + & $(+)$ & \\
\hline Trade policies boosting openness & + & + & & \\
\hline Financial market liberalisation & + & + & $-1+$ & - \\
\hline Prudential regulation & $-1+$ & - & - & \\
\hline Public debt & - & + & + & + \\
\hline Public deficit & - & + & + & + \\
\hline Target inflation rate & - & & - & \\
\hline Target inflation horizon & + & - & & \\
\hline
\end{tabular}




\section{BIBLIOGRAPHY}

Aneglini, P. et al. (2011), "BASEL III : Long-term Impact on Economic Performance and Fluctuations", Bank for International Settlements, Working Papers, No. 338, February.

Ahrend, R., B. Cournede and R. Price (2008), "Monetary Policy, Market Excesses and Financial Turmoil", OECD Economics Department Working Papers, No. 597, OECD Publishing.

Ahrend, R., J. Arnold and C. Moeser (2011), “The Sharing of Macroeconomic Risk: Who Loses (and Gains) from Macroeconomic Shocks?”, OECD Economics Department Working Papers, No. 877, OECD Publishing.

Ahrend, R. and A. Goujard (2012), "International Capital Mobility and Financial Fragility - Part 1. Drivers of Systemic Banking Crises: The Role of Bank-balance-sheet Contagion and Financial Account Structure", OECD Economics Department Working Papers, No. 902, OECD Publishing.

Ahrend, R. and C. Schwellnus (2012), "International Capital Mobility and Financial Fragility - Part 2. The Demand for Safe Assets in Emerging Economies and Global Imbalances: New Empirical Evidence", OECD Economics Department Working Papers, No. 903, OECD Publishing.

Andrews, D., A. Caldera Sánchez and Å. Johansson (2011), "Housing Markets and Structural Policies in OECD Countries", OECD Economics Department Working Papers, No. 836, OECD Publishing.

Andrews, D. and C. Criscuolo (2013), "Knowledge-based Capital, Innovation and Resource Allocation", OECD Economic Policy Papers, No.4, OECD Publishing.

Andrews, D. and D. Rees (2009), "Macroeconomic Volatility and Terms of Trade Shocks", Reserve Bank of Australia Research Discussion Paper, No. RDP 2009-05.

Asea, P.K. and B. Blomberg (1998), “Lending Cycles”, Journal of Econometrics, Vol. 83, pp. 89-128.

Barnes, S. et al. (2011), “The GDP Impact of Reform: A Simple Simulation Framework”, OECD Economics Department Working Papers, No. 834, OECD Publishing.

Bassanini, A. and R. Duval (2006), "Employment Patterns in OECD Countries: Reassessing the Role of Policies and Institutions", OECD Economics Department Working Papers, No. 486.

Bénétrix, A., B. Eichengreen and K. O’Rourke (2012), “How Housing Slumps End”, Economic Policy, Vol. 27, Issue 72, pp. 647-692.

Benk, S., M. Gillman and M. Kejek (2009), “US Volatility of Output and Inflation, 1919-2004: A Money and Banking Approach to a Puzzle", CEPR Discussion Paper, No. 7150.

Bernanke, B. and M. Gertler (2000), "Monetary Policy and Asset Price Volatility”, NBER Working Paper, No. 7559.

Blanchard, O. (2007), "Current Account Deficits in Rich Countries”, IMF Staff Papers, Vol. 54, No. 2, pp. 191219.

Blanchard, O., G. Dell'Ariccia and P. Mauro (2010), "Rethinking Macroeconomic Policy", IMF Staff Position Note, SPN/10/03.

Blanchard, O. and J. Simon (2001), “The Long and Large Decline in U.S. Output Volatility”, Brookings Papers on Economic Activity, No. 1.

Blanchard, O. and J. Wolfers (2000), "The Role of Shocks and Institutions in the Rise of European Unemployment: Aggregate Evidence", The Economic Journal, Vol. 110, No. 462, pp. 1-33. 
Borio, C. (2012), “The Financial Cycle and Macroeconomics: What Have We Learnt?”, BIS Working Papers, No. 395.

Bouis, R. and R. Duval (2011), "Raising Potential Growth after the Crisis: A Quantitative Assessment of the Potential Gains from Various Structural Reforms in the OECD Area and Beyond ", OECD EConomics Department Working Papers, No. 835, OECD Publishing.

Broner, F., T. Didier, A. Erce and S. Schmukler (2013), “Gross Capital Flows: Dynamics and Crises”, Journal of Monetary Economics, Vol. 60, pp. 113-133.

Buch, C., J. Doepke and C. Pierdzioch (2005), "Financial Openness and Business Cycle Volatility", Journal of International Money and Finance, Vol. 24, pp. 744-765.

Catte, P, N. Girouard, R. Price and C. André (2004), "Housing Markets, Wealth and the Business Cycle", OECD Economics Department Working Papers, No. 394, OECD Publishing.

Cerra, V. and S. Saxena (2008), "Growth Dynamics: The Myth of Economic Recovery”, American Economic Review, Vol. 98(1).

Cecchetti, S., A. Flores-Lagunes and S. Krause (2006), "Assessing the Sources of Changes in the Volatility of Real Growth”, NBER Working Paper, No. 11946.

Cecchetti, S., H. Genberg, J. Lipsky and S. Wadhwani. (2000), Asset Prices and Central Bank Policy, Geneva Report on the World Economy 2, CEPR and ICMB.

Céspedes, L., and A. Velasco (2012), "Macroeconomic Performance during Commodity Price Booms and Busts", IMF Economic Review, Vol. 60, pp. 570-599.

Chinn, M. and H. Ito (2008), "Global Current Account Imbalances: American Fiscal Policy versus East Asian Savings", Review of International Economics, Vol. 16, No. 3, pp. 247-264.

Claessens, S., M. Kose and M. M. Terrones (2012), “How Do Business and Financial Cycles Interact?”, Journal of International Economics, Vol. 87, pp. 178-190.

Corsetti, G., K. Kuester, A. Meier and G. Muller (2010), “Deep Consolidation and Fiscal Stabilization of Deep Recessions", American Economic Review, Vol. 100.

Dell'Aricca, G. et al., (2012), "Policies for Macrofinancial Stability: How to Deal with Credit Booms", IMF Staff Discussion Note, SDN/12/06.

Dell'Aricca, G., E. Detragiache and R. Rajan (2008), “The Real Effects of Banking Crises”, Journal of Financial Intermediation, Vol. 17, pp. 89-112.

Drew, A., M. Kennedy and T. Sløk, (2004), "Differences in Resilience between the Euro-Area and US Economies", OECD Economics Department Working Papers, No. 382, OECD Publishing.

Duval, R., J. Elmeskov and L. Vogel (2007), "Structural Policies and Economic Resilience to Shocks", OECD Economic Department Working Papers, No. 567, OECD Publishing.

Duval, R. and L. Vogel (2008), "Economic Resilience to Shocks: The Role of Structural Policies”, OECD Journal: Economic Studies, Vol. 2008/1.

Easterly, W., R. Islam and J. Stiglitz (2001), "Shaken and Stirred: Explaining Growth Volatility”, in B. Pleskovic and N. Stern, eds, Annual World Bank Conference on Development Economics, pp. 191211, The World Bank.

Edey, M. (1994), "Costs and Benefits of Moving from Low Inflation to Price Stability", OECD Economic Studies, No. 23.

Feldstein, M. (1983), "Inflation, Income Taxes and the Rate of Interest: A Theoretical Analysis", Inflation, Tax Rules and Capital Formation, University of Chicago Press. 
Frankel, J. and E. Cavallo (2013), "Does Openness to Trade Make Countries More Vulnerable to Sudden Stops, or Less? Using Gravity to Establish Causality”, NBER Working Paper, No. 10957.

Goodfriend, M. and R. King (1997), “The New Neoclassical Synthesis and the Role of Monetary Policy”, NBER Macroeconomics Annual, Vol. 12, pp. 231-283.

Goodhart, C., B. Hofmann and M. Segoviano (2004), "Bank Regulation and Macroeconomic Fluctuations", Oxford Review of Economic Policy, Vol. 20, No. 4.

Guichard, S. and E. Rusticelli (2010), "Assessing the Impact of the Financial Crisis on Structural Unemployment in OECD Countries”, OECD Economics Department Working Papers, No. 767, OECD Publishing.

Haugh, D., P. Ollivaud and D. Turner (2009), “The Macroeconomic Consequences of Banking Crises in OECD Countries", OECD Economics Department Working Papers, No. 683, OECD Publishing.

Imbs, J. (2002), "Why the Link between Volatility and Growth is both Positive and Negative", CEPR Discussion Paper, No. 3561.

IMF (2011), “Housing Finance and Financial Stability - Back to Basics?”, in: Global Financial Stability Report. Durable Financial Stability: Getting There from Here, pp. 111-157.

Johansson, Å. et al. (2008), “Taxation and Economic Growth”, OECD Economics Department Working Papers, No. 620, OECD Publishing.

Jordà, Ò. (2005), "Estimation and Inference of Impulse Responses by Local Projections”, American Economic Review, Vol. 95(1).

Kaminsky, G. and C. Reinhart (1999), “The Twin Causes of Banking and Balance-of-Payment Problems”, American Economic Review, Vol. 89, No. 3, pp. 473-500.

Karras, G. and F. Song (1996), "Sources of Business-Cycle Volatility: An Exploratory Study on a Sample of OECD Countries”, Journal of Macroeconomics, Vol. 18, No. 4, pp. 621-637.

Kennedy, M. and T. Sløk (2005), "Structural Policy Reforms and External Imbalances", OECD Economics Department Working Papers, No. 415, OECD Publishing.

Kose, M. (2002), “Explaining Business Cycles in Small Open Economies”, Journal of International Economics, Vol. 56, pp. 299-327.

Kose, M, E. Prasad and M. Terrones (2003), "Financial Integration and Macroeconomic Volatility", IMF Working Paper, No. QP/03/50.

Kroft, K. and H. Lloyd-Ellis (2002), "Further Cross-Country Evidence on the Link between Growth, Volatility and Business Cycles", Mimeo, University of California, Berkeley.

Krugman, P. (1998), “It's Baaack: Japan's Slump and the Return of the Liquidity Trap”, Brookings Papers on Economic Activity 2, pp. 137-205.

Lane, P., and G. Milesi-Ferretti (2007), "The External Wealth of Nations Mark II: Revised and Extended Estimates of Foreign Assets and Liabilities, 1970s-2004" Journal of International Economics, 73 (2), pp. 223-250.

Leigh, D. (2009), "Monetary Policy and the Lost Decade: Lessons from Japan", IMF Working Paper, No. WP/09/232.

Levine, R. (2005), “Finance and Growth: Theory and Evidence”, in P. Aghion and S. Durlauf (eds.), Handbook of Economic Growth: Volume 1, Part A, Elsevier, pp. 865-934.

Mendoza, E. (1995), “The Terms of Trade, the Real Exchange Rate and Economic Fluctuations”, International Economic Review, Vol. 36, No. 1, pp. 101-137. 
Nier, E., H. Kong, T. Mancini, H. Hesse, F. Columba, R. Tchaidze and J. Vandenbussche (2012), “The Interaction of Monetary and Macroprudential Policies - Background Paper", IMF.

Noord, P. van den (2006), "Are House Prices Nearing a Peak?: A Probit Analysis for 17 OECD Countries", OECD Economics Department Working Papers, No. 488, OECD Publishing.

OECD (2003), The Sources of Economic Growth in OECD Countries, Paris, OECD Publishing.

OECD (2006), OECD Employment Outlook 2006: Boosting Jobs and Incomes, OECD Publishing.

OECD (2007), OECD EConomic Outlook, Volume 2007/1, No. 81, June, OECD Publishing.

OECD (2010), "Getting it Right: Prudential Regulation and Competition in Banking”, Chapter 6 in, Economic Policy Reforms 2010: Going for Growth, OECD Publishing.

OECD (2011), “Tackling Current Account Imbalances: Is there a Role for Structural Policies?”, Chapter 5 in Economic Policy Reforms 2011: Going for Growth, OECD Publishing.

OECD (2012a), "International Capital Mobility: Which Structural Policies Reduce Financial Fragility?", OECD Economic Policy Papers, No. 2, OECD Publishing.

OECD (2012b), "Structural Reforms in Times of Crisis", in: Economic Policy Reforms 2012: Going for Growth, pp. 17-48, OECD Publishing, Paris.

OECD (2012c), “What Makes Labour Markets Resilient during Recessions?”, OECD Employment Outlook 2012, OECD Publishing.

OECD (2013a), “The Effects of Growth-enhancing Structural Reforms on Other Policy Objectives", in: Economic Policy Reforms 2013: Going for Growth, pp. 57-95, OECD Publishing.

OECD (2013b), “General Assessment of the Macroeconomic Situation”, Economics Department, OECD Economic Outlook, Volume 2013/1, No. 93, June, OECD Publishing.

Phelps, E. (1994), Structural Slumps: The Modern Equilibrium Theory of Unemployment, Interest, and Assets, Harvard University Press.

Ramey, G. and V. Ramey (1995), "Technology Commitment and the Cost of Economic Fluctuations”, NBER Working Paper, No. 3755.

Reinhart, C. and K. Rogoff (2008), “Banking Crises: An Equal Opportunity Menace”, NBER Working Papers, No. 14587.

Roehn, O. (2010), "New Evidence on the Private Saving Offset and Ricardian Equivalence", OECD EConomicS Department Working Papers, No. 762, OECD Publishing.

Schularick, M. and A. Taylor (2012), "Credit Booms Gone Bust: Monetary Policy, Leverage Cycles, and Financial Crises, 1870-2008”, American Economic Review, Vol. 102.

Schwellnus, C. (2013), "International Imbalances: Recent Developments and Medium-term Outlook", OECD Economics Department Working Papers, forthcoming, OECD Publishing.

Slovik, P. and B. Cournède (2011), "Macroeconomic Impact of Basel III", OECD Economics Department Working Papers, No. 844, OECD Publishing.

Summers, L. (1991), "How Should Long-term Monetary Policy Be Determined", Journal of Money, Credit and Banking, Vol. 23, No. 3.

Sutherland, D. and P. Hoeller (2012), "Debt and Macroeconomic Stability: An Overview of the Literature with some Empirics”, OECD Economics Department Working Papers, No. 1006, OECD Publishing.

Sutherland, D. and P. Hoeller (2013), "Growth-promoting Policies and Macroeconomic Stability", OECD Economics Department Working Papers, [forthcoming]. 
Sutherland, D., P. Hoeller, B. Égert and O. Roehn (2010), "Counter-cyclical Economic Policy”, OECD Economics Department Working Papers, No. 760.

Sutherland, D., P. Hoeller, R. Merola and V. Ziemann (2012), "Debt and Macroeconomic Stability”, OECD Economics Department Working Papers, No. 1003, OECD Publishing.

Taylor, A. (2012), "External Imbalances and Financial Crises", Mimeo.

White, W.R. (2009), “Should Monetary Policy Lean or Clean?", Federal Reserve Bank of Dallas Globalisation and Monetary Policy Institute Working Paper, No. 34.

Wong, T., T. Fong, K. Li and H. Choi (2011), "Loan-to-Value as a Macro-prudential Tool - Hong Kong's Experience and Cross-country Experience", Mimeo, Hong Kong Monetary Authority.

Ziemann, V. (2013), "Do Structural Policies Affect Macroeconomic Stability?", OECD Economics Department Working Papers, No. 1075, OECD Publishing. 